\title{
Influence of Tillage Practices on Soil Physical Properties and Growth and Yield of Maize in Jabal al Akhdar, Libya
}

\author{
Gandura 0. Abagandura1 ${ }^{*}$, Gamal Eld-Deen Mohamed Nasr², Nouri Mosa Moumen ${ }^{1}$ \\ ${ }^{1}$ Soil and Water Department, Omar Al-Mukhtar University, Albida, Libya \\ ${ }^{2}$ Department of Agricultural Engineering, Cairo University, Cairo, Egypt \\ Email: ^gabagan@clemson.edu
}

How to cite this paper: Abagandura, G.O., Eld-Deen M. Nasr, G. and Moumen, N.M. (2017) Influence of Tillage Practices on Soil Physical Properties and Growth and Yield of Maize in Jabal al Akhdar, Libya. Open Journal of Soil Science, 7, 118-132. https://doi.org/10.4236/ojss.2017.77010

Received: May 19, 2017

Accepted: July 4, 2017

Published: July 7, 2017

Copyright (c) 2017 by authors and Scientific Research Publishing Inc. This work is licensed under the Creative Commons Attribution International License (CC BY 4.0). http://creativecommons.org/licenses/by/4.0/

\section{Open Access}

\begin{abstract}
Different tillage practices are used for maize cropping in Libya. Yet, the effects of these practices on soil physical properties and maize growth and yield are not known. The objective of this study was to evaluate the effect of different tillage practices on soil physical properties and maize growth and yield in Libya. A field experiment was conducted in 2009 and repeated in 2010 using three tillage practices (conventional tillage (CT), ridge tillage (RT) and zero tillage $(\mathrm{ZT})$ ). Data about soil physical properties (penetration resistance (PR), bulk density (BD), total porosity (TP) and saturated hydraulic conductivity (Ks)) across soil depths, maize growth components (plant height, number of leaves, leaf area index and dry root weight) at 60, 75 and 125 days after planting, and maize yield (grain and stover) at harvest were collected and statistically analyzed in both years. To evaluate the effects of the tillage practices economically, the tillage operation cost and production cost were calculated. The results showed that at the surface layer $(0-20 \mathrm{~cm})$, CT had lower PR and lower BD, but higher TP and Ks compared to RT and ZT. At $20-40 \mathrm{~cm}$ and $40-60 \mathrm{~cm}$ depths, the lower PR and PD and higher TP and Ks were under ZT and RT compared to CT. All maize growth parameters at different times were highest for CT followed by RT and lowest for ZT. The CT practice presented the highest grain and stover yield followed by RT and ZT. However, harvest index was higher where ZT was applied. While tillage operation costs were the highest for CT followed by RT and ZT, the production costs were the highest for ZT followed by RT and CT. In general, the CT practice produced higher maize growth and yield, lower production cost, and higher tillage operation cost than those are planted using RT and ZT practices.
\end{abstract}

\section{Keywords}

Bulk Density, Conventional Tillage, Ridge Tillage, Tillage Cost, Zero Tillage 


\section{Introduction}

Maize is considered one of the most important cereal crops in Libya [1], due to its greater demands for consumption and industrial purposes. Low soil organic matter and pests decrease maize production worldwide [2] [3] and Libya is not exception [4]. For this reason, Libya imported between 450,000 to 650,000 metric tons (18 to 26 million bushels) of maize in 2010 and estimated to import 450,000 tons (18 million bushels) in 2017 [5].

In addition, tillage management greatly affected maize growth in this country. Recent development in mechanization has differentially affected farmers in Africa including Libya. Many farmers use various tillage practices without being aware of the effect of these systems on soil physical properties and plant growth [6]. From the main author's experience in Libya, the farmers usually use moldered plow, chisel plow, and ridger before planting causing the formation of plow pans in some Libyan soils due to the pressure exerted by these machines [7]. Some Libyan farmers still plant without tillage to keep the organic matter from previous year on the surface to help hold the soil in place [6].

Soil tillage, as a necessary practice in crop production, can affect soil physical properties and affect plant growth as a result [8] [9] [10]. According to results of a 15 year experiment, zero tillage recorded higher bulk density and lower infiltration compared to conventional tillage [11]. Deep tillage had lower penetration resistance, lower soil bulk density but higher root length density on loam soil across depths compared to conventional tillage [12]. Conventional tillage achieved lower bulk density, higher water holding capacity and porosity that increased root depth and yield of maize compared to zero tillage [13].

However, there are other reports indicating that tillage practices did not affect soil physical properties and plant growth. No differences in bulk density, saturated hydraulic conductivity and maize yield were recorded between zero tillage and conventional tillage for silty clay loam soil [14]. According to [15], tillage practices had no effect on soil bulk density of the sandy soil surface (eight-year experiment).

Any tillage practice has to improve soil quality, which in turn improves the growth and yield of crops. Claims of different tillage practices can affect soil properties and plant growth are being promoted to Libyan farmers with minimal scientific support. To address this need, the objective of this study was to examine the influence of tillage practices on soil physical properties and maize growth and yield grown on clay loam soil in Libya.

\section{Materials and Methods}

\subsection{Site Location}

For this investigation, a two-year field study was conducted at the Omar Almukter Univrsity Center in Albida, Al Jabel Alkder, Libya (Figure 1) $\left(32^{\circ} 76^{\prime} 272^{\prime \prime} \mathrm{N}\right.$, $21^{\circ} 75^{\prime} 506^{\prime \prime} \mathrm{W}$, elevation $590 \mathrm{~m}$ ) from July to November 2009 and repeated from June to September 2010. The topography was flat $(<1 \%$ slope). The soil was a 


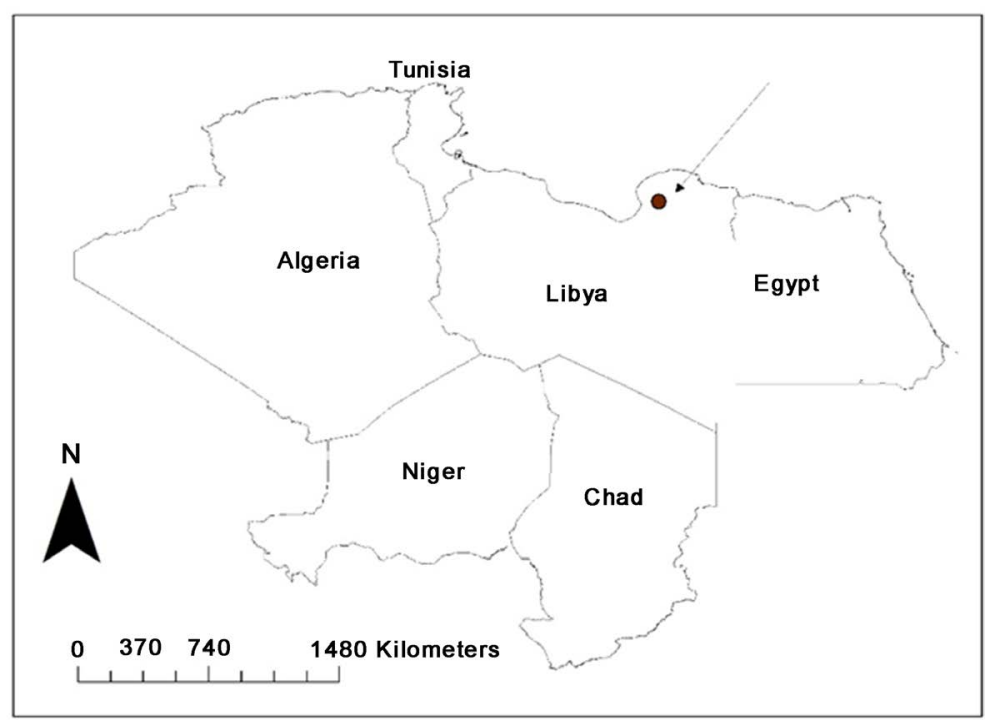

Figure 1. Geographical position of the study area.

mixed, superactive, calcareous, thermic Typic Xerorthents, Shedd Series (USDA classification), formed in residuum weathered from calcareous soft shale (moderately drained and has slow permeability). This area of the country has a plateau type climate with great rainfall and low temperature and used mostly for range and some grain with alternate fallow.

There was no crop growth and the field was left fallow two years prior to the start of the study. Prior to performing the tillage experiment, soil samples were collected from different locations at a depth of $0-20 \mathrm{~cm}$. The soil texture was determined using hydrometer method [16]. Organic matter was determined by the modified Walkey-Black method as suggested by [17]. Available phosphorus (P) and potassium (K) were determined by the method of [18]. The soil in the experimental site was clay loam having an organic matter (6.25\%), $\mathrm{pH}$ (7.30), available $\mathrm{P}\left(1.16 \mathrm{mg} \cdot \mathrm{kg}^{-1}\right)$, available $\mathrm{K}\left(0.05 \mathrm{mg} \cdot \mathrm{kg}^{-1}\right)$, and EC $\left(0.38 \mathrm{dS} \cdot \mathrm{m}^{-1}\right)$ (average of five soil samples).

\subsection{Tillage Implement Treatments}

Four machines include of moldboard, chisel, land leveler and ridger were used in this investigation. A description of each machine is given in Table 1. A tractor with $55.1 \mathrm{kw}$ and a mass of $2800 \mathrm{~kg}$ was used in both years. The manufacturing company of all machines is Simba Tractors Ltd, Nairobi, Kenya.

The experimental area was divided into three blocks $70 \mathrm{~m}$ long and $7 \mathrm{~m}$ wide (blocks separated by a $3 \mathrm{~m}$ spacing) used for each tillage practice. A small block (10 $\mathrm{m}$ long by $5 \mathrm{~m}$ wide) in the beginning of each tested block was used prior to the commencement of the actual test runs to enable the tractor and implement to reach the required speed. Three tillage practices were used to represent the standard primary tillage implements most commonly used for seedbed preparation in this region of the country. The tillage practices included conventional tillage (CT) performed using moldboard plow one pass followed by chisel plow one 
Table 1. The machines description used in this study in 2009 and 2010.

\begin{tabular}{cccc}
\hline Name & Width $(\mathrm{m})$ & Weight $(\mathrm{kg})$ & Specifications \\
\hline Moldboard plow & 1.05 & 400 & Three furrows \\
Chisel plow & 3.25 & 450 & $\begin{array}{c}\text { Thirteen curved shanks, seven in the front, } \\
\text { and six in the back row } \\
\text { Lander leveler }\end{array}$ \\
Ridger & 1.02 & 200 & Single plate \\
\hline
\end{tabular}

pass, lander leveler one pass and ridger one pass, ridge tillage (RT) performed using ridger one pass, and zero tillage (ZT). Treatments were replicated four times. The tillage speeds were as follow: $3.8 \mathrm{hr} \cdot \mathrm{km}^{-1}$ for moldboard plow, 3.6 $\mathrm{hr} \cdot \mathrm{km}^{-1}$ for chisel plow one pass, $4.4 \mathrm{hr} \cdot \mathrm{km}^{-1}$ for lander leveler, and $4.0 \mathrm{hr} \cdot \mathrm{km}^{-1}$ for ridger.

\subsection{Crop Cultivation}

After the tillage practices, Zea mays L. cultivar (Arifiye) seeds were obtained from Agricultural Research Institute in Albida (Libya), planted by hand at a rate of $40 \mathrm{~kg} \cdot \mathrm{ha}^{-1}$ in three rows in each block (each block was divided into three rows) in both years. Surface drip irrigation (common in the region) was applied. Tensiometers (Spectrum Technologies, Inc., USA), one in each block, placed at 10 $\mathrm{cm}$ to $15 \mathrm{~cm}$ below the soil surface to indicate the soil water status. Before field installation, each tensiometer was calibrated. All blocks received the same management (planting, fertilizer, and weed control).

\subsection{Soil Physical Properties Measurements}

Soil physical properties (penetration resistance (PR) bulk density (BD), total porosity (TP) and saturated hydraulic conductivity (Ks) were measured two times, before tillage (Table 2) and after tillage when the maize was at grain physiological maturity, approximately four months from planting in both years [19]. The soil physical properties were determined from different locations in the field at $20 \mathrm{~cm}$ intervals starting from the surface down to a depth of $60 \mathrm{~cm}$.

The PR were determined in the field at depths $0-20 \mathrm{~cm}$ and $20-40 \mathrm{~cm}$ and $40-60 \mathrm{~cm}$ using a hand-pushing penetrometer having maximum measurement range $5000 \mathrm{kPa}$ and $80 \mathrm{~cm}$ depth. Soil penetrometer measurements were made by pushing the penetrometer vertically into the soil at each depth. Undisturbed core samples were collected at $0-20 \mathrm{~cm}, 20-40 \mathrm{~cm}$, and $40-60 \mathrm{~cm}$ depths to measure the $\mathrm{BD}$ and $\mathrm{Ks}$ [14]. The $\mathrm{BD}$ and the Ks were determined on separated samples. BD was calculated using the procedure outlined by [20], then these values were used to calculate the TP using the following equation:

$$
\text { Soil total porosity }=[(1-\mathrm{BD}) / \text { soil particle density }]
$$

the soil particle density assumed to be $2.65 \mathrm{~g} \cdot \mathrm{cm}^{-3}$. The Ks was measured on soil cores in the laboratory using a constant head permeameter [15]. 
Table 2. Soil characteristics of the experiment before tillage as an average of the 2009 and 2010 experiments.

\begin{tabular}{ccccc}
\hline Depth $(\mathrm{cm})$ & $\begin{array}{c}\text { Penetration resistance } \\
\left(\mathrm{kg} \cdot \mathrm{cm}^{-2}\right)\end{array}$ & $\begin{array}{c}\text { Bulk density } \\
\left(\mathrm{g} \cdot \mathrm{cm}^{-3}\right)\end{array}$ & $\begin{array}{c}\text { Total porosity } \\
(\%)\end{array}$ & $\begin{array}{c}\text { Saturated hydraulic } \\
\text { conductivity }\left(\mathrm{cm} \cdot \mathrm{h}^{-1}\right)\end{array}$ \\
\hline $0-20$ & 2.75 & 1.27 & 52.07 & 0.161 \\
$20-40$ & 2.14 & 1.28 & 51.69 & 0.357 \\
$40-60$ & 2.44 & 1.30 & 50.94 & 0.231 \\
\hline
\end{tabular}

\subsection{Growth and Yield Parameters Measurements}

Percentage of emerged seedlings (PE) was calculated [21] for each tillage practice as follow:

$$
\mathrm{PE}=[(\text { total emerged seedlings } / \mathrm{m}) /(\text { number of seeds planted } / m)] \times 100
$$

five plants for each tillage practice were sampled randomly at 60,75 , and 120 days after planting to measure plant height, number of leaves, leaf area index and root weight. Plant height was measured as the vertical distance between the ground and the highest living part of the plant with a ruler. Number of leaves per plant was determined by counting all the leaves on each plant. The leaf area index was calculated [22] using the following equation:

$$
\text { Leaf Area Index }=0.75 \text { (Leaf length } \times \text { Leaf width })
$$

for total dry shoot weight determination, the above ground samples were weighed and oven-dried at $80^{\circ} \mathrm{C}$ and weighed again.

The dry root mass at various times and depths were determined. Maize roots were sampled with a soil core (a diameter of $10 \mathrm{~cm}$ and a height of $10 \mathrm{~cm}$ ). The soil cores were taken to a depth of $60 \mathrm{~cm}$ in each block at four different locations. The cores were then taken to the lab and the soil and the roots were soaked in a solution containing $40 \mathrm{~g} /$ liter sodium hexametaphosphate in a 1:5 soil solution ratio [23]. Roots floated to the surface and were skimmed from the surface with a fine wire strainer. By subsequent washing in tap water roots and organic debris were separated. The roots were oven-dried at $80^{\circ} \mathrm{C}$ and weighed.

At harvest (120 days after planting), grain and stover (above-ground biomass minus grain) yield were measured. Both the mass of grain and mass of stover were calculated after drying and converted to a per hectare basis at $14 \%$ moisture content [24]. Harvest index (\%) was calculated on percentage basis by using the following formula:

$$
\text { Harvest index = economic yield/biological yield }
$$

climate data during the two growing seasons was collected from a weather station located approximately $500 \mathrm{~m}$ from the field.

\subsection{Costs of Tillage Operation and Production Measurements}

To estimate tillage operation cost, the cost associated with each tillage practice include machinery, fuel and labor was calculated totally as $\$ \mathrm{ha}^{-1}$ in both years. 
Machinery costs were based on the data provided by Agricultural Research Institute in Albida, Libya. They were calculated according to the hours of use including costs for insurance, tax, and average repair costs. Fuel consumption was measured by using a secondary tank with a level marked tube and bulb with volume $140 \mathrm{~cm}^{3}$ [25]. Labor was measured with a stopwatch for each tillage practice. No land costs included since land costs were the same across tillage practices [26]. Production cost $\left(\$ \cdot \operatorname{ton}^{-1}\right.$ for grain + stover) include all variable costs for seed, lime, fertilizer, herbicides, and insecticides for each tillage practices were calculated.

\subsection{Experimental Design and Data Analysis}

A completely randomized block design was used in this study. Tillage was randomized within blocks. Data across the two years was assessed (residuals were homogeneous across years (Levene's test) and normal distributed (Shapiro-Wilk test), and then was statistically analyzed using the analysis of variance (ANOVA) to test the effects of tillage practices on the soil physical properties and maize growth and yield. All calculations were performed using SAS (SAS Institute Inc., North Carolina, USA). Year was first tested as a factor and found not significant for all metrics. Therefore, year was considered as a random factor in the model. Differences between the three tillage practices were compared by the Fisher LSD test. Differences between the means were considered to be statistically significant at $\mathrm{P}<0.05$

\section{Results and Discussion}

\subsection{Climate Conditions}

Mean monthly temperature, precipitation and relative humidity during the study period in 2009 and 2010 are shown in Figure 2. The accumulated precipitation during the growing seasons was $7.4 \mathrm{~cm}$ in 2009 and $10.7 \mathrm{~cm}$ in 2011. The mean temperature during the growing season was $22.9^{\circ} \mathrm{C}$ and $24^{\circ} \mathrm{C}$ and the highest relative humidity was $72 \%$ and $71 \%$ in 2009 and 2010, respectively.

\subsection{Soil Physical Properties}

\subsubsection{Penetration Resistance and Bulk Density}

The PR and BD had similar trend to some extent at all depths which was expected because high BD produces high PR [27] [28]. At all depths, both parameters were significantly different among tillage practices (Figure 3(a), Figure 3(b)).

As expected, the PR and the BD for the soil surface $(0-20 \mathrm{~cm})$ were the highest for ZT followed by RT, and the least was for CT (Figure 3(a), Figure 3(b)), indicating that lack or minimum of disturbance produces an increase in both parameters measured at the soil surface. The lower PR and BD under CT compared to other tillage practices were probably due to tillage operations breaking the soil surface and producing loose soil [28] [29] [30]. Several studies documented that zero tillage recorded higher PR for the soil surface compared to tilled soil [31] [32] [33] [34] [35]. 


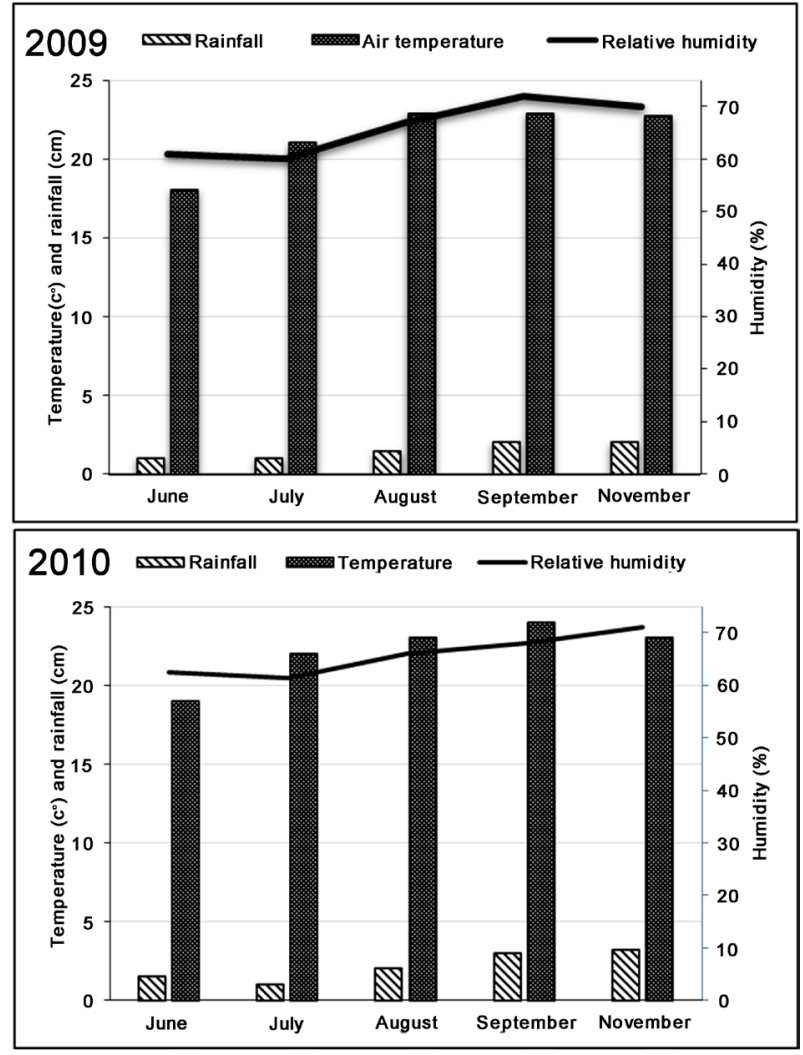

Figure 2. Mean monthly temperature, precipitation and humidity during the study period in 2009 and 2010.

For $20-40 \mathrm{~cm}$ and $40-60 \mathrm{~cm}$ depths, the lowest PR and PD were under ZT followed by RT and CT due to machinery weights used in CT (Figure 3(a), Figure 3(b)). These results agree with [36] and [37] who reported that zero tillage led to higher $\mathrm{PR}$ and $\mathrm{BD}$ in the soil surface, but lower in both parameters in the deeper soil depths as compared to excessive tillage.

\subsubsection{Total Porosity and Saturated Hydraulic Conductivity}

The TP and Ks were found to have some similarity trend due to the fact that increasing soil TP enhances Ks and visa verse [38] [39]. Both parameters were influenced by the different tillage practices (Figure $4(\mathrm{a})$, Figure $4(\mathrm{~b})$ ) at the three soil depths.

At $0-20 \mathrm{~cm}$ soil depth, while the highest TP and Ks were recorded under CT, the lowest were under ZT (Figure 4(a), Figure 4(b)). [40] also found higher TP and $\mathrm{Ks}$ at the soil surface under conventional tillage compared to zero tillage. Similar to BD and RP, the trend of TP and Ks at the subsurface depths (20 - 40 $\mathrm{cm}, 40-60 \mathrm{~cm}$ ) was reversed. The highest TP and Ks were recorded under ZT and the lowest were under CT (Figure 4(a), Figure 4(b)). This result is probably due to machinery weights causing an increase in $\mathrm{BD}$ of the deeper depths under CT compared to ZT (Figure 3(b)) resulting decrease in TP and Ks under this practice. The relationship of $\mathrm{BD}$ and $\mathrm{TP}$ is reciprocal. As one increases, the other decreases. 


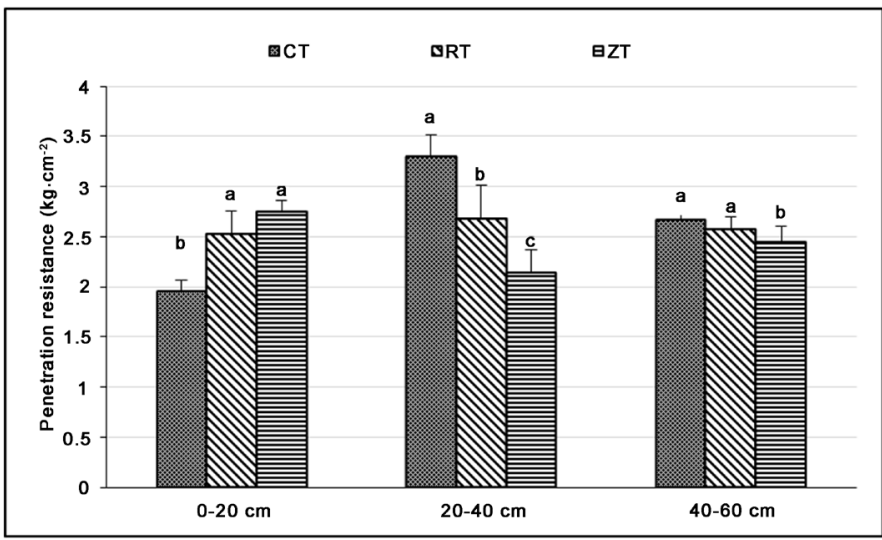

(a)

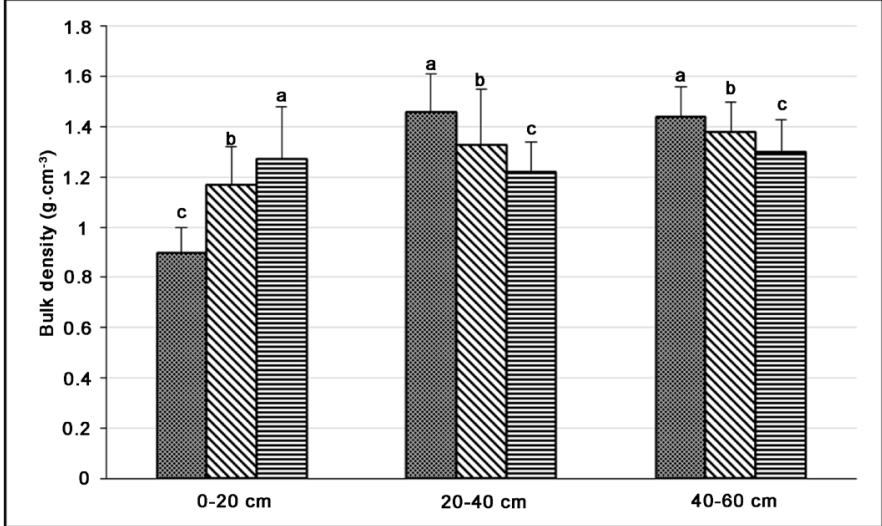

(b)

Figure 3. Penetration resistance (a) and bulk density (b) at different depths for the three tillage practices. Means are labelled with letters to denote statistical significance, a (largest), b (middle) and c (smallest). Within each column, means followed by the same letter are not significantly different at significant level $=0.05$. The error bars represent the standard deviation. $\mathrm{CT}=$ moldboard plow, chisel plow, lander leveler and ridger, $\mathrm{RT}=$ ridger, $\mathrm{ZT}=$ no tillage.

\subsection{Maize Growth and Yield}

The PE differed among tillage practices $(\mathrm{p}=0.0206)$. The highest PE was recoded under CT followed by RT and the lowest under ZT (Figure 5). The topsoil TP of the CT was higher compared to ZT (Figure 4(a)) which facilities free movement of air and moisture in the soil and thus increases the PE under CT. Similarly, [41] [42] found that zero tillage reduce the PE of maize compared to conventional tillage.

The tillage practices showed also significant difference in the maize growth. Plant height, number of leaves, leaf area index and dry weight of shoot at 60, 75, and 120 days after planting were the highest for CT and the lowest for ZT (Table 3).

The positive effect of tillage compared to zero tillage was observed in other maize growth studies. Taller plant [43] [44], higher number of leaves per plant and higher leaf area index [22] [45] of maize were found in tilled soil compared to zero tillage. 


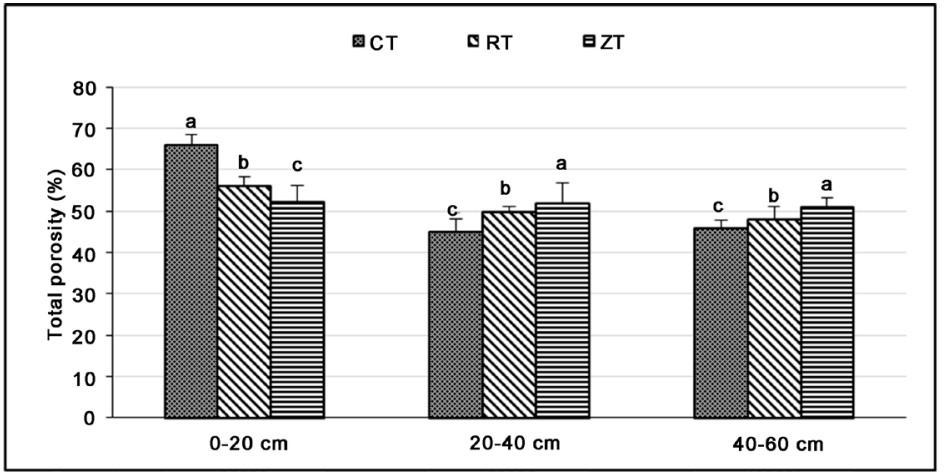

(a)

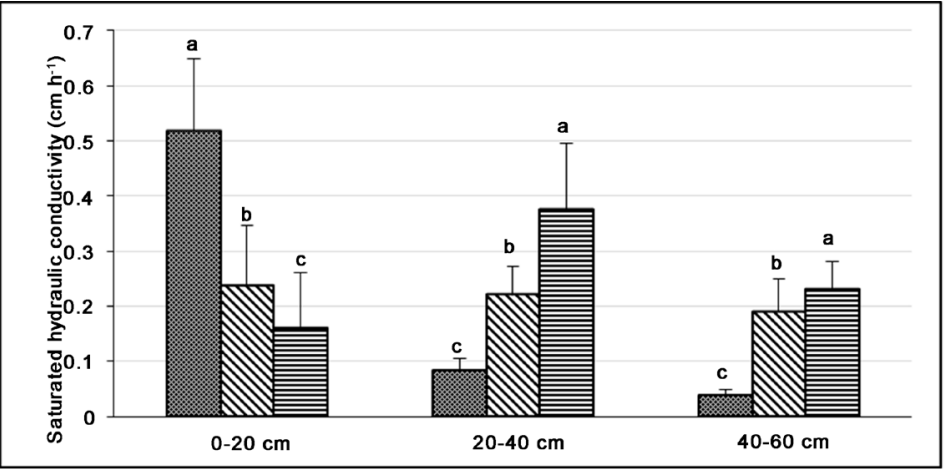

(b)

Figure 4. Total porosity (a) and saturated hydraulic conductivity (b) at different depths for the three tillage practices. Means are labelled with letters to denote statistical significance, a (largest), b (middle) and c (smallest). Within each column, means followed by the same letter are not significantly different at significant level $=0.05$. The error bars represent the standard deviation. $\mathrm{CT}=$ moldboard plow, chisel plow, lander leveler and ridger, $\mathrm{RT}=$ ridger, $\mathrm{ZT}=$ no tillage.

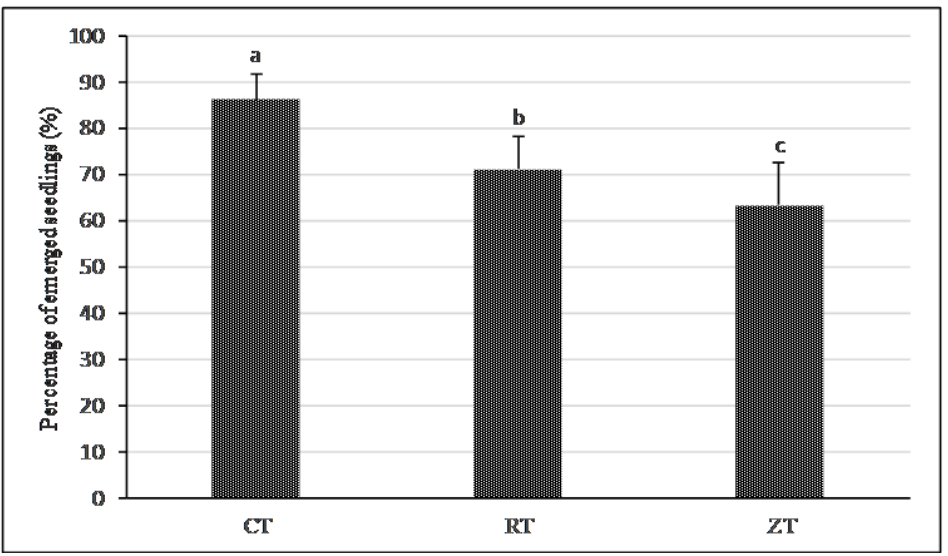

Figure 5. Percentage of emerged seedlings of maize for the three tillage practices. Means are labelled with letters to denote statistical significance, a (largest), b (middle) and c (smallest).Within each column, means followed by the same letter are not significantly different at significant lev$\mathrm{el}=0.05$. The error bars represent the standard deviation. $\mathrm{CT}=$ moldboard plow, chisel plow, lander leveler and ridger, $\mathrm{RT}=$ ridger, $\mathrm{ZT}=$ no tillage. 
Table 3. Effect of tillage practices on maize growth at different times during the season.

\begin{tabular}{|c|c|c|c|}
\hline \multirow[t]{2}{*}{ Tillage } & \multicolumn{3}{|c|}{ Days after planting } \\
\hline & 60 & 75 & 120 \\
\hline & \multicolumn{3}{|c|}{ Plant height $(\mathrm{cm})$} \\
\hline $\mathrm{CT}$ & $250.00 \mathrm{a}$ & $245.33 \mathrm{a}$ & $250.00 \mathrm{a}$ \\
\hline $\mathrm{RT}$ & $160.00 \mathrm{~b}$ & $200.33 \mathrm{~b}$ & $204.91 \mathrm{~b}$ \\
\hline $\mathrm{ZT}$ & $150.33 \mathrm{c}$ & $192.00 \mathrm{c}$ & $200.33 c$ \\
\hline \multirow[t]{2}{*}{$\mathrm{P}$-value } & 0.0107 & 0.00839 & 0.0054 \\
\hline & \multicolumn{3}{|c|}{ Number of leaves } \\
\hline $\mathrm{CT}$ & $14.50 \mathrm{a}$ & $\mathrm{CT}$ & $14.50 \mathrm{a}$ \\
\hline $\mathrm{RT}$ & $13.00 \mathrm{~b}$ & $\mathrm{RT}$ & $13.00 \mathrm{~b}$ \\
\hline $\mathrm{ZT}$ & $12.33 \mathrm{c}$ & $\mathrm{ZT}$ & $12.33 \mathrm{c}$ \\
\hline \multirow[t]{2}{*}{ P-value } & 0.0079 & $\mathrm{P}$-value & 0.0079 \\
\hline & \multicolumn{3}{|c|}{ Leaf area index $\left(\mathrm{cm}^{-2}\right)$} \\
\hline $\mathrm{CT}$ & $1230.66 \mathrm{a}$ & CT & $1230.66 \mathrm{a}$ \\
\hline $\mathrm{RT}$ & $1002.00 \mathrm{~b}$ & $\mathrm{RT}$ & $1002.00 \mathrm{~b}$ \\
\hline $\mathrm{ZT}$ & $751.06 \mathrm{c}$ & $\mathrm{ZT}$ & $751.06 \mathrm{c}$ \\
\hline \multirow[t]{2}{*}{$\mathrm{P}$-value } & 0.0116 & $\mathrm{P}$-value & 0.0116 \\
\hline & \multicolumn{3}{|c|}{ Dry weight of shoot $(\mathrm{g})$} \\
\hline $\mathrm{CT}$ & $272.63 \mathrm{a}$ & $\mathrm{CT}$ & $272.63 \mathrm{a}$ \\
\hline $\mathrm{RT}$ & $180.32 \mathrm{~b}$ & $\mathrm{RT}$ & $180.32 \mathrm{~b}$ \\
\hline $\mathrm{ZT}$ & $157.53 \mathrm{c}$ & $\mathrm{ZT}$ & $157.53 \mathrm{c}$ \\
\hline $\mathrm{P}$-value & 0.0400 & $\mathrm{P}$-value & 0.0400 \\
\hline
\end{tabular}

Although the highest root dry mass across all depths at all times was found under CT and the lowest under ZT, these differences were not significant (data not shown). These results are similar to that of [46] who reported higher dry matter of root in conventional tillage compared to zero tillage in sandy loam soil.

The effect of tillage practices on grain and stover at harvest are shown in Figure 6. The ZT presented the lowest grain and stover yield in comparison with the other tillage practices (Figure 6). These results may be due to the lack of soil loosening for providing conditions favorable to crop growth and yield under ZT practice. [47] [22] also reported higher maize yield under CT compared to ZT practice. Soil tillage has a great influence upon the harvest index of maize recording lower harvest index (32\%) when CT was applied compared to ZT (62\%) and RT (53\%). In other words, the physiological effectiveness of maize crop to partition the dry matter into its cost effective (grain) yield than generation of whole-plant biomass increased under ZT and RT compared to CT. These results are not in line with the findings of [48] who stated that higher harvest index was observed where conventional tillage was applied compared to minimum tillage. In other study [49], disking determined higher values of the harvest index than plowing. 


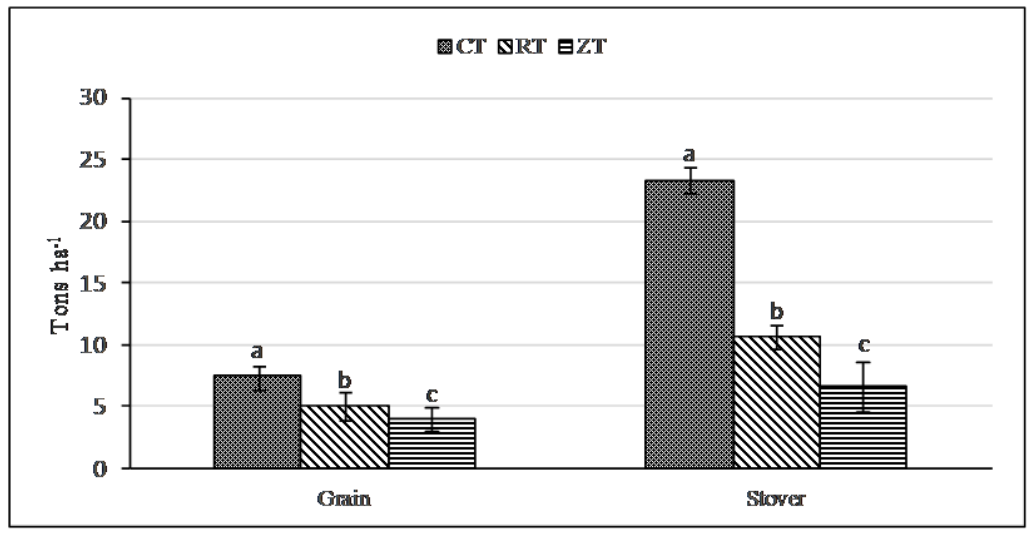

Figure 6. Maize grain and stover yield $\left(\right.$ ton $\cdot \mathrm{ha}^{-1}$ ) at harvest for the three tillage practices. Means are labelled with letters to denote statistical significance, a (largest), b (middle) and c (smallest). Within each column, means followed by the same letter are not significantly different at significant level $=0.05$. The error bars represent the standard deviation. CT $=$ moldboard plow, chisel plow, lander leveler and ridger, $\mathrm{RT}=$ ridger, $\mathrm{ZT}=$ no tillage.

\subsection{Tillage Operation and Production Costs}

Operation and production costs for each tillage practice are shown in Table 4. Estimates of total machinery, fuel and labor cost were the least for ZT practice compared to RT and CT (Table 4).

The operation tillage costs for CT were approximately $\$ 76.50$ greater than for the RT (Table 4). On the other hand, the production costs were the highest for ZT compared to other practices. Although seed, fertilizer, lime and insecticide expenses were slightly similar among tillage practices, herbicide costs were higher in ZT and RT compared to CT (data not shown), probably due to the fact that zero or minimum tillage production rely exclusively on herbicides for weed control [50] [51].

\section{Conclusions}

Inappropriate tillage practices are considered a major constraint to maize production in Jabal al Akhdar, Libya. Based on the observed results:

- The three tillage practices had significant effects on the measured soil physical properties.

- Growth and development of maize were highly correlated with the type and degree of plowing.

- Harvest index was significantly affected by tillage practices and maximum harvest index was recorded where ZT was applied.

- The cost for seed preparation increased with increasing the usage of machines.

- The cost of the maize yield increased when soil left without tillage.

Long term tillage experiment (> two seasons) would be required to detect changes in soil physical properties and maize growth as a result of the tillage practices. 
Table 4. Tillage operation and production costs for each tillage practice.

\begin{tabular}{ccc}
\hline Tillage & Tillage cost $\left(\$ \cdot \mathrm{ha}^{-1}\right)$ & Production cost $\left(\$ \cdot\right.$ ton $\left.^{-1}\right)$ \\
\hline CT & $93.75 \mathrm{a}$ & $2.26 \mathrm{c}$ \\
RT & $17.24 \mathrm{~b}$ & $4.32 \mathrm{~b}$ \\
ZT & $*$ & $5.25 \mathrm{a}$ \\
P-value & 0.0217 & 0.0380 \\
\hline
\end{tabular}

\section{Acknowledgements}

This research was supported in part by funds administered through the Omar Al-Mukhtar University, Albida, Libya.

\section{References}

[1] Alldrissi, M., Sbeita, A., Jebriel, A., Zintani, A. and Shreidi, H. (1996) Libya: Country Report to the FAO International Technical Conference on Plant Genetic Resources.

http://www.fao.org/fileadmin/templates/agphome/documents/PGR/SoW1/east/LIB YA.pdf

[2] Copeland, P.J. and Crookston, R.K. (1992) Crop Sequence Affects Nutrient Composition of Corn and Soybean Grown Under High Fertility. Agronomy Journal, 84, 503-509. https://doi.org/10.2134/agronj1992.00021962008400030028x

[3] Riedell, W.E., Pikul, J.L., Jaradat, A.A. and Schumacher, T.E. (2009) Crop Rotation and Nitrogen Input Effects on Soil Fertility, Maize Mineral Nutrition, Yield, and Seed Composition. Agronomy Journal, 101, 870-879.

https://doi.org/10.2134/agronj2008.0186x

[4] Abagandura, O.G. and Park, D. (2016) Libyan Agriculture: A Review of Past Efforts, Current Challenges and Future Prospects. Journal of Natural Sciences Research, 6, 57-67.

[5] Abagandura, O.G. (2016) Using Soil Conditioners to Improve Soil Physiochemical Properties and Agricultural Productivity in Libya. Ph.D. Thesis, Clemson University, SC, USA.

[6] Omar, S. (2017) pers. comm., 6 May. Employee in the Secretariat of Agriculture, Albida, Libya.

[7] Kausar, M.A., Chaudhry, F.M., Rashid, A., Latif, A. and Alam, S.M. (1976) Micronutrient Availability to Cereals from Calcareous Soils. Plant Soil, 45, 397-410. https://doi.org/10.1007/BF00011702

[8] Strudley, M.W., Green, T.R. and Ascough, J.C. (2008) Tillage Effects on Soil Hydraulic Properties in Space and Time: State of the Science. Soil Tillage Research, 99, 4-48. https://doi.org/10.1016/j.still.2008.01.007

[9] Schwen, A., Bodner, G., Scholl, P., Buchan, G.D. and Loiskandl, W. (2011) Temporal Dynamics of Soil Hydraulic Properties and the Water-Conducting Porosity under Different Tillage. Soil Tillage Research, 113, 89-98. https://doi.org/10.1016/j.still.2011.02.005

[10] Costa, J.L., Aparicio, V. and Cerdà, A. (2015) Soil Physical Quality Changes under Different Management Systems after 10 Years in the Argentine Humid Pampa. Solid Earth, 6, 361-371. https://doi.org/10.5194/se-6-361-2015

[11] Gómez, J.A., Giráldez, J.V., Pastor, M. and Fereres, E. (1999) Effects of Tillage Me- 
thod on Soil Physical Properties, Infiltration and Yield in an Olive Orchard. Soil and Tillage Research, 52, 167-175.

[12] Ji, B., Zhao, Y., Mu, X., Liu, K. and Li, C. (2013) Effects of Tillage on Soil Physical Properties and Root Growth of Maize in Loam and Clay in Central China. Plant, Soil and Environment, 59, 295-302.

[13] Senjobi, B.A., Ande, O.T. and Okulaja, A.E. (2013) Effects of Tillage Practices on Soil Properties under Maize Cultivation on Oxic Paleustalf in South Western Nigeria. Open Journal of Soil Science, 3, 163-168. https://doi.org/10.4236/ojss.2013.33019

[14] Shirani, H., Hajabbasi, M.A., Afyuni, M. and Hemmat, A. (2002) Effects of Farmyard Manure and Tillage Systems on Soil Physical Properties and Corn Yield in Central Iran. Soil and Tillage Research, 68, 101-108.

[15] Lal, R. (1997) Long-Term Tillage and Maize Monoculture Effects on a Tropical Alfisol in Western Nigeria. I. Crop Yield and Soil Physical Properties. Soil and Tillage Research, 42, 145-160.

[16] Sheldrick, B.H. and Wang, C. (1993) Particle Size Distribution. In: Carter, M.R. Ed., Soil Sampling and Methods of Analysis, Lewis Publications/CRC Press, Boca Raton, FL, 499-511.

[17] Nelson D.W. and Sommers L.E. (1982) Total Carbon, Organic Carbon, and Organic Matter. In: Page, A.L., et al., Eds., Methods and Soil Analysis. Part 2. Chemical and Microbial Properties, Agronomy Monograph No. 9, 2nd Edition, ASA-SSSA, Madison, 539-557.

[18] Olsen S.R. and Sommers L.E. (1982) Phosphorus. In: Page, A.L., et al., Eds., Methods and Soil Analysis. Part 2. Chemical and Microbial Properties, Agronomy Monograph No. 9, 2nd Edition, ASA-SSSA, Madison, 403-430.

[19] Miriti, J.M., Kironchi, G., Esilaba, A.O., Gachene, C.K.K., Heng, L.K. and Mwangi, D.M. (2013) The Effects of Tillage Systems on Soil Physical Properties and Water Conservation in a Sandy Loam Soil in Eastern Kenya. Journal of Soil Science Environmental Management, 4, 146-154. https://doi.org/10.5897/JSSEM2013.0395

[20] Anderson, J.M. and Ingram, J.S.I. (1993) Tropical Soil Biology and Fertility. In: $A$ Handbook of Methods, 2nd Edition, C.A.B. International, Wallingford, UK, 221.

[21] Bayhan, Y., Kayisoglu, B. and Gonulol, E. (2002) Effects of Soil Compaction on Sunflower Growth. Soil and Tillage Research, 68, 31-38.

[22] Aikins, S.H.M., Afuakwa, J.J. and Owusu-Akuoko, O. (2012) Effect of Four Different Tillage Practices on Maize Performance under Rainfed Conditions. Agriculture and Biology Journal of North America, 1, 1-51.

[23] Ben-Asher, J. and Silberbush, M. (1992) Root Distribution Under Trickle Irrigation: Factors Affecting Distribution and Comparison among Methods of Determination. Journal of Plant Nutrition, 15, 783-794. https://doi.org/10.1080/01904169209364362

[24] Wang, X., Zhou, B., Sun, X., Yue, Y., Ma, W. and Zhao, M. (2015) Soil Tillage Management Affects Maize Grain Yield by Regulating Spatial Distribution Coordination of Roots, Soil Moisture and Nitrogen Status. PLOS ONE, 10, e0129231.

[25] Ranjbarian, S., Mohammad, A. and Javad, J. (2015) Performance of Tractor and Tillage Implements in Clay Soil. Journal of the Saudi Society of Agricultural Sciences, 16, 154-162.

[26] Archer, D.W., Pikul, J.L. and Riedell, W.E. (2002) Economic Risk, Returns and Input Use under Ridge and Conventional Tillage in the Northern Corn Belt, USA. Soil and Tillage Research, 67, 1-8.

[27] Cassel, D.K. (1982) Tillage Effects on Soil Bulk Density and Mechanical Impedance. 
In: Unger, P.W. and Van Doren, D.M., Eds., Predicting Tillage Effects on Soil Physical Properties and Processes, ASA and SSSA, Madison, WI, 45-67.

[28] Lampurlanés, J. and Cantero-Martinez, C. (2003) Soil Bulk Density and Penetration Resistance under Different Tillage and Crop Management Systems and Their Relationship with Barley Root Growth. Agronomy Journal, 95, 526-536. https://doi.org/10.2134/agronj2003.0526

[29] Busari, M.A., Kukal, S.S., Kaur, A., Bhatt, R. and Dulazi, A.A. (2015) Conservation Tillage Impacts on Soil, Crop and the Environment. International Soil and Water Conservation Research, 3, 119-129.

[30] Al-Hamed, S.A., Wahby, M.F. and Sayedahmed, A.A. (2016) Effect of Three Tillage Implements on Potato Yield and Water Use Efficiency. American Journal of Experimental Agriculture, 12, 1-6. https://doi.org/10.9734/AJEA/2016/24950

[31] Wander, M.M. and Bollero, G.A. (1999) Soil Quality Assessment of Tillage Impacts in Illinois. Soil Science Society of America Journal, 63, 961-971. https://doi.org/10.2136/sssaj1999.634961x

[32] Ferreras, L.A., Costa, J.L., Garcia, F.O. and Pecorari, C. (2000) Effect of No-Tillage on Some Soil Physical Properties of a Structural Degraded Petrocalcic Paleudoll of the Southern "Pampa" of Argentina. Soil and Tillage Research, 54, 31-39.

[33] Fabrizzi, K.P., Garcia, F.O., Costa, J.L. and Picone, L.I. (2005) Soil Water Dynamics, Physical Properties and Corn and Wheat Responses to Minimum and No-Tillage Systems in the Southern Pampas of Argentina. Soil and Tillage Research, 81, 57-69.

[34] Singh, B. and Malhi, S.S. (2006) Response of Soil Physical Properties to Tillage and Residue Management on Two Soils in a Cool Temperate Environment. Soil and Tillage Research, 85, 143-153.

[35] Alvarez, R. and Steinbach, H.S. (2009) A Review of the Effects of Tillage Systems on Some Soil Physical Properties, Water Content, Nitrate Availability and Crops Yield in the Argentine Pampas. Soil and Tillage Research, 104, 1-15.

[36] Grant, C.A. and Lafond, G.P. (1993) The Effects of Tillage Systems and Crop Sequences on Soil Bulk Density and Penetration Resistance on a Clay Soil in Southern Saskatchewan. Canadian Journal of Soil Science, 73, 223-232. https://doi.org/10.4141/cjss93-024

[37] Buschiazzo, D.E., Panigatti, J.L. and Unger, P.W. (1998) Tillage Effects on Soil Properties and Crop Production in The Subhumid and Semiarid Argentinean Pampas. Soil and Tillage Research, 49, 105-116.

[38] Lin, H.S., McInnes, K.J., Wilding, L.P. and Hallmark, C.T. (1999) Effects of Soil Morphology on Hydraulic Properties: I. Quantification of Soil Morphology. Soil Science Society of America Journal, 63, 948-954. https://doi.org/10.2136/sssaj1999.634948x

[39] Coquet, Y., Vachier, P. and Labat, C. (2005) Vertical Variation of Near-Saturated Hydraulic Conductivity in Three Soil Profiles. Geoderma, 126, 181-191.

[40] Carof, M., De Tourdonnet, S., Coquet, Y., Hallaire, V. and Roger-Estrade, J. (2007) Hydraulic Conductivity and Porosity under Conventional and No-Tillage and the Effect of Three Species of Cover Crop in Northern France. Soil Use and Management, 23, 230-237. https://doi.org/10.1111/j.1475-2743.2007.00085.x

[41] Smith, M.A., Carter, P.R. and Imholte, A.A. (1992) No-Till vs. Conventional Tillage for Late-Planted Corn Following Hay Harvest. Journal of Production Agriculture, 5, 261-264. https://doi.org/10.2134/jpa1992.0261

[42] Lithourgidis, A.S., Tsatsarelis, C.A. and Dhima, K.V. (2005) Tillage Effects on Corn Emergence, Silage Yield, and Labor and Fuel Inputs in Double Cropping with 
Wheat. Crop Science, 45, 2523-2528. https://doi.org/10.2135/cropsci2005.0141

[43] Kayode, J. and Ademiluyi, B. (2004) Effect of Tillage Methods on Weed Control and Maize Performance in Southwestern Nigeria Location. Journal of Sustainable Agriculture, 23, 39-45. https://doi.org/10.1300/J064v23n03_05

[44] Khurshid, K., Iqbal, M., Arif, M.S. and Nawaz, A. (2006) Effect of Tillage and Mulch on Soil Physical Properties and Growth of Maize. American Journal of Agricultural and Biological Sciences, 8, 593-596.

[45] Liu, K. and Wiatrak, P. (2012) Corn Production Response to Tillage and Nitrogen Application in Dry-Land Environment. Soil and Tillage Research, 124, 138-143.

[46] Diaz-Zorita, M. (2000) Effect of Deep-Tillage and Nitrogen Fertilization Interactions on Dryland Corn (Zea mays L.) Productivity. Soil and Tillage Research, 54, 11-19.

[47] Videnović, Ž., Simić, M., Srdić, J. and Dumanović, Z. (2011) Long Term Effects of Different Soil Tillage Systems on Maize (Zea mays L.) Yields. Plant, Soil and Environment, 57, 186-192.

[48] Shahid, M.N., Zamir, M.S.I., Haq, I.U., Khan, M.K., Hussain, M., Afzal, U. and Ali, I. (2016) Evaluating the Impact of Different Tillage Regimes and Nitrogen Levels on Yield and Yield Components of Maize (Zea mays L.). American Journal of Plant Sciences, 7, 789-797. https://doi.org/10.4236/ajps.2016.76073

[49] Ion, V., Dicu, G., Dumbrava, M., Temocico, G., Alecu, I.N., Basa, A.G. and State, D. (2015) Harvest Index at Maize in Different Growing Conditions. Romanian Biotechnological Letters, 20, 10951-10960.

[50] Reicosky, D.C. and Allmaras, R.R. (2003) Advances in Tillage Research in North American Cropping Systems. Journal of Crop Production, 8, 75-125. https://doi.org/10.1300/J144v08n01_05

[51] Chauhan, B.S., Gill, G.S. and Preston, C. (2006) Tillage System Effects on Weed Ecology, Herbicide Activity and Persistence: A Review. Animal Production Science, 46, 1557-1570. https://doi.org/10.1071/EA05291

\section{Submit or recommend next manuscript to SCIRP and we will provide best service for you:}

Accepting pre-submission inquiries through Email, Facebook, LinkedIn, Twitter, etc. A wide selection of journals (inclusive of 9 subjects, more than 200 journals)

Providing 24-hour high-quality service

User-friendly online submission system

Fair and swift peer-review system

Efficient typesetting and proofreading procedure

Display of the result of downloads and visits, as well as the number of cited articles

Maximum dissemination of your research work

Submit your manuscript at: http://papersubmission.scirp.org/

Or contact ojss@scirp.org 